\title{
Pentingnya Budaya Gotong Royong di Lingkungan Masyarakat dapat Menciptakan Persatuan dan Kesatuan Bangsa Indonesia
}

\author{
Mitha Larasati Vidya Ningtiyas \\ IIK STRADA INDONESIA \\ mithalarasati1803@gmail.com
}

\begin{abstract}
ABSTRAK
Indonesia merupakan negara yang kaya akan budaya, suku, agama, ras, dan adat istiadat. Nilai budaya yang menjadi karakteristik bangsa Indonesia seperti, silatuhrami, ramah tamah dalam masyarakat yang menjadi keistimewaan dalam diri bangsa Indonesia serta, gotong royong yang sering masyarakat lakukan untuk membangun desa mereka. Gotong royong merupakan penerapan dari nilai Pancasila dan penerapannya dalam interaksi sosial di kehidupan sehari-hari sering kali di lakukan oleh masyarakat untuk menciptakan rasa kekeluargaan. Dengan adanya budaya gotong royong di masyarakat dapat menciptakan rasa persatuan dan kesatuan dalam diri masyarakat.
\end{abstract}

Kata kunci: Gotong royong, tujuan, Persatuan

\section{Latar Belakang}

Gotong royong bersal dari kata gotong yang berarti "bekerja", dan royong yang berarti "bersama". Gotong royong juga sudah menjadi ciri khas dari bangsa Indonesia. Perilaku ini dapat menunjukkan bahwa kepribadian bangsa Indonesia menjadi budaya yang telah tertanam dalam diri masyarakat sejak dulu. Samapai saat ini, kegiatan gotong royong masih melekat dalam diri masyarakat. Ini dapat terlihat dari aktivitas kerja bakti ynag sering masyarakat lakukan. Gotong royong bukan hanya tentang menyelesaikan pekerjaan, tetapi juga untuk mempererart rasa kekeluargaan dan persatuan dalam diri masyarakat.

Tanpa adanya gotong royong di tengah-tengah masyarakat sebuah kebersamaan dan rasa persatuan kesatuan tidak akan pernah mereka rasakan dalam hati mereka. Pergertian gotong royong sendiri adalah suatu kegiatan yang dilakukan secara bersama-sama dan bersifat suka rela agar kegiatan yang dikerjakan dapat berjalan dengan lancar, mudah dan ringan sehingga pekerjaan yang berat dapat terasa ringan dan cepat terselesaikan. 


\section{Kasus/Masalah}

Sejak muncunya arus arus globalisasi dan modernisasi yang oleh sebagian orang dianggap sebagai peluang hebat, tetapi memiliki dampak negative terutama pada nilai-nilai krbersamaan dalam hidup masyarakat. Budaya gotong royong akan memudar apabila rasa kebersamaan mulai menurun dan setiap pekerjaan tidak ada lagi bantuan sukarela, bahkan sekarang telah dinilai dengan uang atau materi. Kegiatan gotong royong baik di perdesaan maupun kota, wajib dijaga bersama dengan menerapkanya dalam kehidupan sehari-hari.

\section{Tinjauan Pustaka}

Budaya gotong royong sebagai ciri bangsa Indonesia harus selalu dipertahankan. Hal ini sebagai bentuk nyata dari solidaritas sosial dalam kehidupan bermasyarakat. Setiap warga negara yang terlibat di dalamnya memiliki hak untuk dibantu dan berkewajiban untuk membantu. Disini terdapat azaz timbal balik yang saling menguntungkan. Gotong royong juga mengajari setiap orang rela untuk berkorban. Pengorbanan tersebut dapat diberbentuk seperti berkorban waktu, pikiran, hingga uang. Semua pengorbanan dilakukan demi kepentingan bersama. Masyarakat harus rela mengesampingkan kebutuhan pribadi untuk memenuhi kepentingan bersama.

Perilaku gotong royong dapat mencerminkan kebersamaan yang tumbuh dalam lingkungan masyarakat. Dengan gotong royong, masyarakat mau bekerja secara bersama-sama untuk saling mambantu orang lain membangun fasilitas umum yang dapat dimanfaatkan bersama. Dengan demikian rasa kebersamaan yang terjalin dalam kegiatan gotong royong dapat melahirkan rasa persatuan antar mansyarakat yang lebih kuat sehingga masyarakat mampu menghadapi maslah yang muncul dengan bermusyawarah bersama.

\section{Pembahasan}

Gotong royong merupakan budaya yang telah tumbuh dan berkembang dalam kehidupan sosial masyarakat Indonesia sebagai warisan budaya yang telah turun tememurun. Gotong royong adalah bentuk kerjasama kelompok masyarakat untuk mencapai suatu hasil positif dari tujuan yang ingin dicapai secara mufakat dan musyawarah bersama. Gotng royong muncul atas dorongan kesadaran dan semangat untuk mengerjakan serta menanggung akibat dari suatu karya, tanpa memikirkan dan menguntungkan diri sendiri, melainkan untuk kebahagian bersama.

Bergotong royong membuat masyarakat lebih kompak dan juga dapat mengenal satu sama lain. Dengan bergotong royong kita bisa saling tolong menolong seperti saat kita mendirikan rumah, mengerjakan sawah, membantu 
tetangga yang sedang berduka, hingga saling bahu membahu untuk memperjuangkan negaranya. Gotong royong juga memiliki tujuan seperti:

$>$ Membuat setiap pekerjaan menjadi ringgan.

$>$ Mempererat rasa persatuan dan kesatuan.

$>$ Menghemat pengeluaran.

$>$ Dapat menyelesaikan pekerjaan dengan cepat.

$>$ Mempererat tali persaudaran antar sesama, karena dengan gotong royong kita dapat berkumpul dengan keluarga dan tetangga.

Manfaat gotong royong yaitu:

- Lingkungan menjadi bersih dan terjaga.

- Menjalin dan menumbuhkan rasa solidaritas dalam lingkungan masyarakat.

- Persaudaraan dan kebersamaan sesame warga semakin erat dan masyarakat dapat saling mengenal satu sama lain.

- Dapat tercipta rasa ketentraman dan kedamaian atar sesame warga atau masyarakat.

\section{Kesimpulan}

Gotong royong dapat muncul atas dorongan kesadaran dan semangat untuk mengerjaka serta menanggung akibat dari suatu karya, tanpa memikirkan dan menguntungkan akibat dari suatu karya, tanpa harus memikirkan dan menguntungkna diri sendiri, melainkan untuk kebahagian bersama. Persaudaraan dan kebersamaan sesame warga dapat semakin erat dan masyarakat dapat saling mengenal satu sama lain.

\section{Daftar Pustaka}

Panjaitan, S. C., \& Dewantara, A. (2019). Gotong Royong sebagai Prinsip Masyarakat Indonesia untuk Menanggapi Konflik Multikulturalisme. https://scholar.google.com/scholar?hl=id\&as_sdt=0\%2C5\&q=Gotong+Royon g+sebagai+Prinsip+Masyarakat+Indonesia+untuk+Menanggapi+Konflik+Mul tikulturalisme\&btnG=\#d=gs_cit\&u=\%2Fscholar\%3Fq\%3Dinfo\%3AKZIKY WlzXwIJ\%3Ascholar.google.com\%2F\%26output\%3Dcite\%26scirp\%3D0\%2 $\underline{6 \mathrm{hl} \% 3 \mathrm{Did}}$

Effendi, T. N. (2013). Budaya Gotong-Royong Masyarakat dalam Perubahan Sosial Saat Ini. Jurnal Pemikiran Sosiologi, 2(1). https://scholar.google.com/scholar?hl=id\&as_sdt=0,5\&q=Budaya+Gotong-

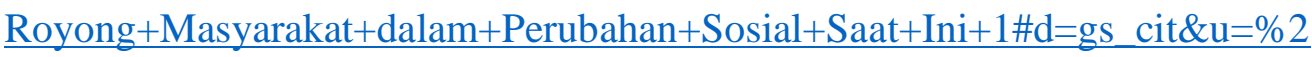
Fscholar\%3Fq\%3Dinfo\%3A46CDyv- 
rWNkJ\%3Ascholar.google.com\%2F\%26output\%3Dcite\%26scirp\%3D0\%26h $1 \% 3 \mathrm{Did}$

Lestari, E. Y. (2019). Menumbuhkan kesadaran nasionalisme generasi muda di era globalisasi melalui penerapan nilai-nilai Pancasila. ADIL Indonesia Journal, 1(1).

https://scholar.google.com/scholar?hl=id\&as sdt=0\%2C5\&q=MENUMBUH KAN+KESADARAN+NASIONALISME+GENERASI+MUDA+DI+ERA++ GLOBALISASI+MELALUI+PENERAPAN+NILAI-

NILAI+PANCASILA\&btnG=\#d=gs_cit\&u=\%2Fscholar\%3Fq\%3Dinfo\%3A OpwYz70Lg2MJ\%3Ascholar.google.com\%2F\%26output\%3Dcite\%26scirp\% 3D0\%26hl\%3Did

Febrina, F. (2019). Gotong Royong Sebagai Natura Bangsa Indonesia untuk Mengatasi Krisis Keberagaman Budaya. https://scholar.google.com/scholar?hl=id\&as_sdt=0\%2C5\&q=GOTONG+RO YONG+SEBAGAI+NATURA+BANGSA+INDONESIA+UNTUK+MENG ATASI+KRISIS+KEBERAGAMAN+BUDAYA\&btnG=\#d=gs_cit\&u=\%2Fs cholar\%3Fq\%3Dinfo\%3Ai7aaM1ZpVg4J\%3Ascholar.google.com\%2F\%260 utput\%3Dcite\%26scirp\%3D0\%26hl\%3Did 